Article

\title{
Encouraging Vietnamese Household Recycling Behavior: Insights and Implications
}

\author{
The Ninh Nguyen ${ }^{1, *}$, Hoang Viet Nguyen ${ }^{2}$, Antonio Lobo ${ }^{3}$ and The Son Dao ${ }^{4}$ \\ 1 Faculty of Marketing, Vietnam University of Commerce, Ho Tung Mau Road, Hanoi 122414, Vietnam \\ 2 Department of Research Administration, Vietnam University of Commerce, Ho Tung Mau Road, \\ Hanoi 122414, Vietnam; nhviet@vcu.edu.vn \\ 3 Faculty of Business and Law, Swinburne University of Technology, Hawthorn, VIC 3122, Australia; \\ alobo@swin.edu.au \\ 4 Faculty of Economics and Law, Vietnam University of Commerce, Ho Tung Mau Road, Hanoi 122414, \\ Vietnam; daotheson@gmail.com \\ * Correspondence: ngtheninh@gmail.com
}

Academic Editor: Marc A. Rosen

Received: 23 December 2016; Accepted: 23 January 2017; Published: 26 January 2017

\begin{abstract}
This research aims to provide new insights into various determinants affecting household recycling. By focusing on Vietnam, this research also extends knowledge about sustainable behavior in emerging markets, which are the major culprits in terms of greenhouse gas emissions. Hypotheses were developed as a result of the critical review of relevant studies in the fields of marketing, psychology, and economics, and then tested using a quantitative survey data. Structured questionnaires were administered to Vietnamese respondents which yielded 486 usable responses. Multivariate statistics reveal that all the determinants influenced their recycling behavior except for moral norms. Attitude towards the importance of recycling exerted the strongest influence, followed by subjective norms and warm glow respectively. On the other hand, attitude towards the inconvenience of recycling significantly reduced recycling behavior. The research findings have important implications for strategies aimed at promoting recycling behavior. Communication and education programs should emphasize how household recycling contributes to environmental protection, as well as stress intrinsic rewards when recycling. Public media campaigns should feature opinion leaders and attractive communicators, who can effectively apply social pressure to perform recycling behavior. Organizations should also make every effort to make recycling more convenient.
\end{abstract}

Keywords: recycling behavior; attitudes; norms; warm glow; emerging markets; Vietnam

\section{Introduction}

The growing awareness that human activity challenges the environment quality and natural resources has led to the prominence of sustainability research and recognition of the urgent need to encourage more responsible consumption [1-4]. Households are the key contributor to the alarmingly increasing rate of the quantity of solid wastes which cause environmental degradation [5,6]. In addition to investment in waste treatment systems, household recycling, which involves separating newspaper, cardboard, glass bottles, aluminum cans, plastic containers, and other recyclable materials at the source [7], is of utmost importance for environmental protection [8,9]. Essentially, recycling of household solid wastes is a cost-effective way of (a) efficiently utilizing landfill capacity; (b) minimizing the disposal of solid waste hence decreasing costs; (c) enhancing environmental quality; and (d) increasing socio-economic sustainability $[10,11]$. Hence, encouraging recycling behavior is imperative, and should be prioritized especially in emerging markets, where rapid population growth, 
increased consumption, urbanization, and industrialization collectively cause a significant increase in solid waste generation by households [5,12].

Both government and private organizations play an important role in addressing social and environmental problems by promoting human and societal welfare [13]. Many firms have increasingly engaged in community environmental campaigns and recycling programs. The engagement in pro-environmental initiatives demonstrates both environmental corporate social responsibility $[14,15]$ as well as increase in corporate financial performance [16-18]. Hence the development of community recycling programs and the encouragement of participation by individuals in such programs are highly strategic [19], which requires comprehensive understanding of the motivations of those involved in recycling. Additionally, firms need to factor the perceptions of the target audience when designing environmental communications which are aimed at persuading them to adopt pro-environmental behaviors [20].

The extant literature has sought to elucidate determinants and motives of individuals relating to recycling. Several studies in the area of recycling behavior have built upon rational choice theories such as the Theory of Planned Behavior-TPB [21], and the Theory of Reasoned Action-TRA [22]. These studies have emphasized the influence of factors such as knowledge, attitudes, subjective norms, and perceived behavioral control on recycling behavior [23-26]. Another major research stream in this area has focused on the importance of morality in explaining recycling [27]. That is, people may engage in recycling behavior because they feel morally obliged to perform that action. Notably, scholars the like of Bratt [28], Shaw et al. [29], and Botetzagias et al. [30] demonstrate that the inclusion of moral and ethical obligation reduces the gap between environmental attitudes and behavior, hence improving the predictability of the TPB. Furthermore, studies have emphasized that some individuals choose to recycle waste regardless of the personal costs, as they receive intrinsic rewards which are attributed to the warm glow effect [31,32]. These individuals experience intrinsic satisfaction gained from acting in an environmental manner $[33,34]$. Nevertheless, given that the decision to recycle is typically complex [30], future research is necessary to provide a more comprehensive understanding of factors influencing recycling behavior. As most pro-environmental studies have been conducted in Western and developed countries, further studies in emerging markets would certainly enrich the evolving literature. Additionally, an in-depth understanding of associated influencers is critical for informing both policymakers and organizations which strive to obtain a large percentage of the population to participate in or to support recycling activities [35].

Inspired by the above mentioned arguments, this research adopts an integrative approach to better understand people's decision to recycle household wastes. Specifically, the research objectives are to:

(i) Better understand how various determinants and motives influence household recycling behavior;

(ii) Increase the knowledge about environmentally sustainable behavior in emerging markets by focusing on Vietnam;

(iii) Make recommendations for policymakers and organizations which aim to promote household recycling behavior.

The remainder of this paper is organized as follows. It first discusses recycling behavior in Vietnam. Thereafter it provides a more detailed, critical review of the literature on sustainable consumption, particularly regarding recycling behavior, and presents proposed hypotheses. This is followed by the research methodology and the key findings of this study. Finally, there is a comprehensive discussion on the implications of this study including future research directions.

\section{Recycling of Household Solid Wastes in Vietnam}

The concept of recycling is not new to the Vietnamese people, especially to those living in urban cities. During the period of 2006 to 2009, the 3R (reduce, reuse, recycle) initiative funded by the 
Japan International Cooperation Agency was implemented by Hanoi City Urban Environmental Company in selected central wards [36]. The key activities of the 3R initiative included provision of waste bins, introduction of new source-separated waste collection bins and environmental education for children [37]. The government extended the 3R policy and confirmed its determination of increasing the quantity of national waste separation at source and also by implementing the National Strategy on Integrated Solid Waste Management through to 2025 [38]. Apart from governmental initiatives, market-based organizations also make efforts to support and enhance household recycling. Leading manufacturers of electronic products including HP, Apple, and Microsoft have established the Vietnamese Recycling Platform to enhance waste collection and recycling processes [39]. Other companies such as PepsiCo, Intel Products, and Tetra Pak have supported and joined the Waste Recycling Day which is an annual event aiming at increasing awareness and knowledge about recycling activities [40].

The study of recycling behavior in an emerging country like Vietnam is extremely important owing to four main reasons. First, rapid economic growth and increasing consumption have caused significant increase in solid waste production and air pollution which has resulted in a doubling of greenhouse gas emission in the last 15 years [41,42]. Second, given the large market base comprising a population exceeding 91 million and rising consumer spending [43,44], Vietnam is an attractive market for organizations and investors. Third, only a few studies have been conducted to date in the area of sustainable behavior and recycling in Vietnam [12,37,45,46], hence very little is known about Vietnamese consumers' sustainable and conservation behavior [47]. The country has a collectivist culture [48], and therefore provides an interesting comparison against the typically individualist cultures encountered when investigating the more developed countries. Fourth, despite extensive efforts by the government and private organizations, the majority of Vietnamese consumers apparently suffer from a lack of knowledge and money to live sustainably [45]. They also feel that the government and other organizations need to provide better recycling systems.

\section{Literature Review and Hypotheses Development}

\subsection{Attitudes and Beliefs about Recycling}

Attitudes refer to an individual's judgement that performing a certain behavior would yield positive or negative consequences [21]. The attitude-behavior relationship has received significant interest from academic researchers in the field of recycling behavior [49-52]. Attitudes investigated in past research comprise both general attitudes including environmental concern and the new environmental paradigm as well as specific attitudes referring to specific beliefs about recycling $[51,53,54]$. Notably, McCarty and Shrum [11,55] suggest that attitudes towards recycling should be operationalized using two constructs, i.e., the importance of recycling for the environment and the inconvenience of recycling. Such an approach addresses both consumers' beliefs about benefits and difficulties associated with recycling, thus emphasizing the conflict between collective societal gain and self-interest when recycling. More specifically, whilst recycling is benefical to the society as a whole owing to its environmental benefit, it involves cost to an individual because of the extra time and effort required to separate solid wastes [31].

Empirical evidence demonstrates that, whilst attitude towards the importance of recycling positively affects reported recycling behaviors, the inconvenience associated with recycling significantly impedes such behaviors $[11,56,57]$. Hence the following hypotheses have been developed:

Hypothesis $\mathbf{1}\left(\mathbf{H}_{\mathbf{1}}\right)$. Attitudes toward the importance of recycling are positively associated with recycling behavior.

Hypothesis $2\left(\mathbf{H}_{\mathbf{2}}\right)$. Attitudes toward the inconvenience of recycling are negatively associated with recycling behavior. 


\subsection{Subjective Social Norms}

Subjective social norms regulate behavior by exerting "perceived social pressure to perform or not to perform the behavior" [21], and they may serve as a reference point for inducing individuals to contribute to environmental preservation [58]. Individuals who are uncertain about the consequences of environmentally sustainable behavior may seek support from others who are important to them [28].

Prior empirical studies have revealed diverse findings about the role of subjective social norms in people's recycling decisions. Terry et al. [24] and Schwab et al. [6] negate the importance of support from parents and friends by concluding that the relationship between respondents' subjective norms and their recycling behavior is not significant. Nevertheless, authors like Schultz [59], Biswas et al. [60] and do Valle et al. [54] demonstrate that social norms explain a significant variance in waste recycling activities. Notably, Abbott et al. [31] suggest that policymakers should lean on social norms rather than other measures to promote recycling. Hence the following has been hypothesized:

Hypothesis $\mathbf{3}\left(\mathbf{H}_{3}\right)$. Subjective social norms are positively associated with recycling behavior.

\subsection{Moral Norms}

Moral norms reflect "personal beliefs about the moral correctness or incorrectness of performing a specific behavior" [25]. Nielsen and McGregor [61] argue that moral norms are internalized and they affect an individual's thoughts, feelings, and behaviors, independent of the originating context. Likewise, Schwartz and Howard [62] suggest that personal moral norms influence behavioral standards that are self-reinforcing.

Personal morality is a key facilitator of various ethical and environmentally sustainable behaviors [4,63-65]. A survey by Davies et al. [23] reveals that respondents perceive a moral obligation to recycle their household waste. More recently, Botetzagias et al. [30] conclude that moral norm exerts a stronger influence on recycling intention than attitude. Hence, the following hypothesis has been formulated:

Hypothesis $4\left(\mathbf{H}_{4}\right)$. Moral norms are positively associated with recycling behavior.

\subsection{Warm Glow}

Traditionally environmental programs are designed based on extrinsic incentives, such as money or other utilitarian benefits [32,33]. Nevertheless, some studies have challenged this view, arguing that individuals are motivated by emotions intrinsically derived from acting pro-environmentally [66-68], especially when they perceive such behaviors are difficult to perform [69]. Warm glow has been identified as a crucial intrinsic driver of environmentally sustainable behavior [70]. This concept originates in the economic-based model of warm-glow giving [71], which demonstrates that if people enjoy the act of giving, the warm-glow motive dominates the altruistic motive which reflects contribution to public good. That is, individuals make donations because they gain positive emotional feeling from the act of helping others [71,72]. In psychology literature, warm glow sits parallel to the concepts of intrinsic motivation [73] and intrinsic satisfaction [74]. Accordingly, people are intrinsically motivated to perform an activity because it is inherently enjoyable $[75,76]$.

Hartmann and Apaolaza Ibáñez $[77,78]$ suggest that warm glow positively influences consumers' intention to buy green energy brands. Empirical studies by De Young [33,74] conclude that individuals and households engage in reusing and recycling activities because of the internal contentment, i.e., intrinsic satisfaction related to such behavior. Hence the following hypothesis has been developed:

Hypothesis $\mathbf{5}\left(\mathbf{H}_{\mathbf{5}}\right)$. Warm glow is positively associated with recycling behavior. 
Figure 1 depicts the hypothetical relationships between the constructs investigated in this study.

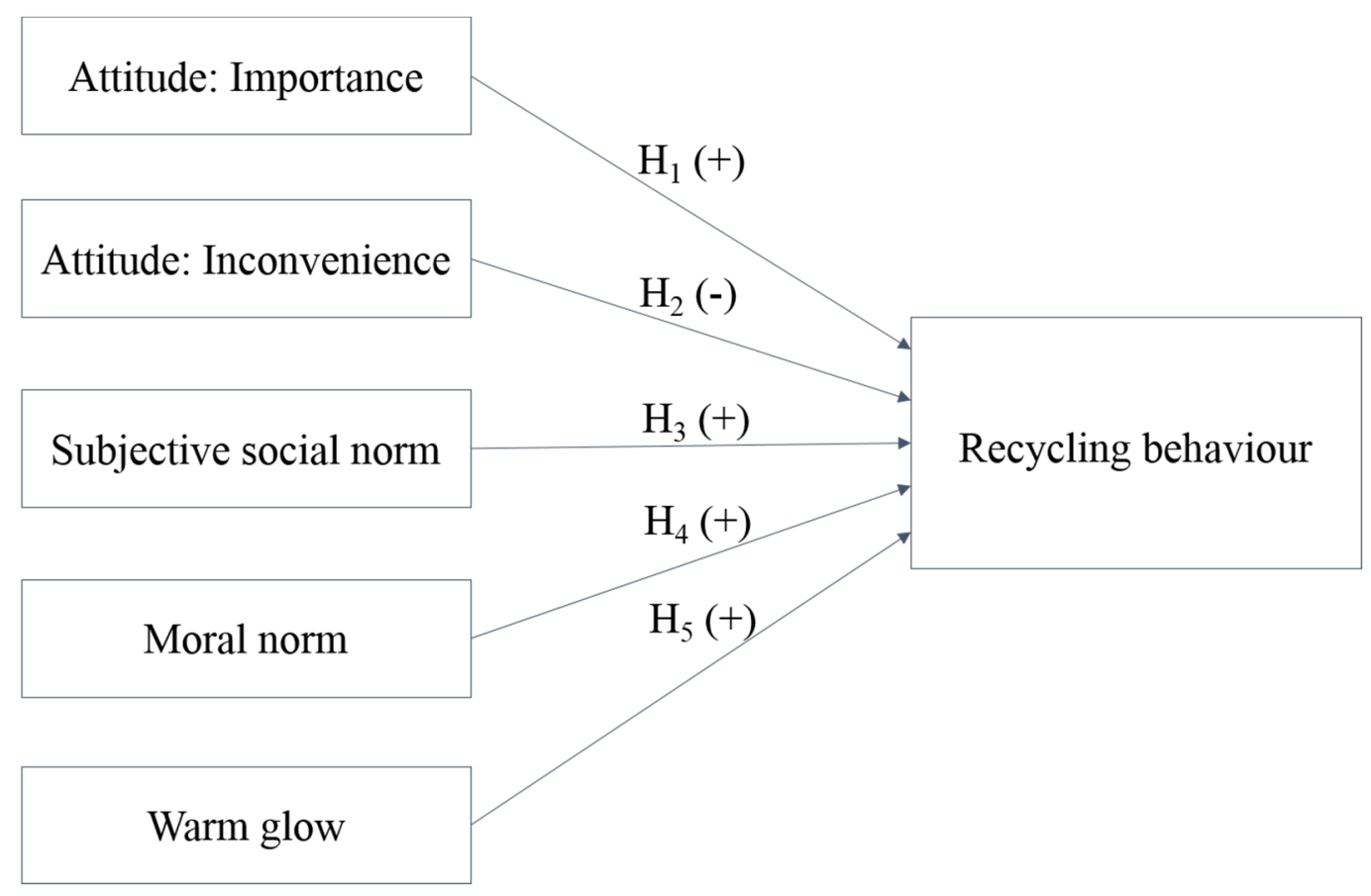

Figure 1. The proposed research model.

\section{Research Methodology}

This research has adopted a hypo-deductive research design. Accordingly, hypotheses were developed as a result of the critical review of extant literature, and proposed variables were operationalized using validated items. Quantitative data was then collected through the use of survey employing a structured questionnaire. Such a methodology is prevalent in the field of ethical and recycling behavior [11,79-81].

\subsection{Operationalization of Constructs}

The items used to operationalize the constructs of the proposed conceptual model were adopted from existing validated scales. Furthermore, three focus groups each consisting of eight recyclers with different demographics were conducted to adapt the scales to the Vietnamese context [82]. A Vietnamese researcher of pro-environmental behavior acted as the moderator who faciliated participants' discussion on topics such as beliefs, attitudes, motivations, and barriers associated with recycling activities. Following these focus groups, some items of the initial scales were modified in terms of wording and content.

McCarty and Shrum's [11] scales for measuring attitudes towards recycling was used. Three items for measuring attitude towards the importance of recycling were designed to seek respondents' views on how recycling contributes to environmental protection. Another three items for measuring attitudes toward the inconvenience of recycling were intended to elicit respondents' difficulties associated with recycling. Specifically, the original item of "I hate to wash out bottles" was replaced by the item "There is not enough room to store the items being recycled" as all the participants in the focus groups considered the lack of space for storing recyclable solid wastes as the key barrier to recycling.

To measure subjective social norm, two items were adapted from Tonglet et al.'s [25] and Thøgersen's [65] scales. These items sought respondents' views on social pressure to perform recycling behavior. 
Respondents' moral norms were measured by adapting four items from Tonglet et al.'s [25] study. These items were developed to elicit respondents' moral obligation to recycle household solid waste

Four items for measuring warm glow were developed using inputs from Nunes and Schokkaert's [83] and Hartmann and Apaolaza Ibáñez's [78] scales. These items were intended to capture respondents' positive feelings gained from recycling.

Previous research operationalized recycling behavior as the extent to which respondents engaged in a number of self-reported recycling activities [50,52]. In this study, three items for measuring recycling behavior asked respondents' how frequently they recycle metal cans, plastic containters and glass jars/bottles. Such a selection is based on the inputs of the focus groups and also on the fact that these materials comprise a major portion of municipal solid wastes (MSW) in Vietnam [5]. It is interesting to note that the recycling behavior did not include the recycling of paper cardboard. Justifications of this include that the majority of the focus groups' participants were not concerned about this activity, and that paper cardboard accounted for only $2 \%$ of MSW in Vietnam [5].

All items operationalizing all the constructs outlined above were measured using 5-point scales. To measure the five potential determinants, the scale was anchored at 1 for 'strongly disagree' and 5 for 'strongly agree'. To measure self-report recycling behavior, the scale was anchored at 1 for 'never' to 5 for 'always'.

\subsection{Pre-Test of the Questionnaire}

A pre-test was conducted for the purpose of diagnosing and eliminating potential problems associated with answering the questions and recording the data. Using the cognitive interviewing method [84], the experienced researcher acted as facilitator in eight in-depth interviews with recyclers who agreed to respond. These interviewees were different from those who participated in the focus groups mentioned above. Each interviewee was asked to complete the survey in the researcher's presence and then to verbalize their thoughts on key issues such as time of completion, clarity of instructions, question wording, and layout [85]. Following the deliberations of the pre-tests, minor changes to the wording and layout of the questionnaire were made.

The final questionnaire contained a screening question ("Have you ever recycled household waste, e.g., cans, containers, jars/bottles?"), items measuring all the constructs, and questions about respondents' demographic profile. Care was taken to ensure that the presentation of each of the constructs was counterbalanced to reduce the likelihood of any order effects. Furthermore, the exogenous variables were separated from the endogenous. The foregoing measures are recommended by Podsakoff et al. [86] as procedural remedies for dealing with potential effects of common method bias.

\subsection{Sample and Data Collection}

The respondents who qualified for this study were Vietnamese citizens who engaged in the recycling of household waste. Non-probability volunteer sampling was used because there was not a sampling frame. Experienced research assistants administered the questionnaires to eligible respondents who agreed to voluntarily provide responses at public parks, universities, markets, and shopping malls in five districts around the city of Hanoi. Specifically, respondents were selected by approaching every third available person at the site, and they were verbally assured that their anonymity and privacy would be respected and that there were no right or wrong answers. These procedures assisted in reducing respondents' evaluation apprehension and social desirability in providing responses [86]. The research assistants completed questionnaires based on what the respondents said. During a period of three months, a total of 743 questionnaires was distributed. The number of returned questionnaires was 522, thus the response rate was $70 \%$. Out of these, 25 were eliminated for having missing values, and a futher 11 were removed as being outliers which were identified using boxplot. Therefore, the final effective sample in this study was 486 . 
Table 1 shows the key demographic characteristics of the respondents. As reported in the Statistical Yearbook [44], the ratio of men to women in Vietnam is approximately 49:51, which is similar to that obtained in this study's sample. Furthermore, given that the percentage of Vietnamese people aged 20-29, 30-39, 40-49, 50-59, and 60+ was $18.9,15.6,13.3,8.6$, and $8.7 \%$ respectively, it is reasonable to assume that the age groups in the sample represent similar proportion. The results of the Population and Housing Survey showed that the marriage incidence of Vietnamese people aged 18 and over was $67 \%$ which is equivalent to that obtained in the sample [41]. Finally, the respondents' educational background represents the trend for the majority of Vietnamese people to hold degree qualifications [44].

Table 1. Demographic profile of the study's respondents.

\begin{tabular}{lcc}
\hline \multicolumn{1}{c}{ Demographics } & Frequency & Percentage $\%$ \\
\hline Gender & 234 & \\
Male & 252 & 58.1 \\
Female & & \\
\hline Age & 142 & 29.2 \\
18-29 & 112 & 23.0 \\
$30-39$ & 96 & 19.8 \\
$40-49$ & 66 & 13.6 \\
$50-59$ & 70 & 14.4 \\
60+ & & \\
\hline Marital status & 143 & 29.4 \\
Single/never married & 312 & 64.2 \\
Currently married & 31 & 6.4 \\
Others & & \\
\hline Educational background & 25 & 18.1 \\
High school and below & 89 & 59.3 \\
Professional degree & 288 & 17.3 \\
Bachelor's degree & 84 & 65.7 \\
Postgraduate degree & & 34.3 \\
\hline Children living at home & 319 & \\
YES & 167 & \\
NO & &
\end{tabular}

\section{Data Analysis}

The data analysis included three stages. Preliminary analysis was initially performed to examine any potential effects of common method bias as well as to assess the validity of scales. Subsequently, descriptive statistics and bivariate correlations were used to describe basic features of the collected data. Finally, the proposed hypotheses were tested using multiple regression.

\subsection{Preliminary Analysis}

Common method bias may cause measurement errors by affecting constructs' reliabilities and validities [87]. In addition to the procedural remedies mentioned above, a Harman's single-factor test was conducted to further assess if there were any potential effects of common method bias on the measures used in this study $[88,89]$. Accordingly, all items for measuring the constructs were subjected to an exploratory factor analysis using SPSS 24.0. The unrotated factor solutions demonstrated that the single factor explained only $34 \%$ of the variance in the variables. Hence, it is reasonable to assume that common method bias was unlikely to affect the sample data [86].

The results of reliability analysis are depicted in Table 2. Cronbach's alpha values $(\alpha)$ for constructs ranged from 0.732 to 0.913 , which were above the threshold of 0.7 . Also, corrected item-to-total 
correlations were all greater than 0.5 . Hence, all the measures have relatively high internal consistency of reliability $[90,91]$.

Table 2. Measurement items and reliability.

\begin{tabular}{|c|c|c|}
\hline Construct and Items & $\begin{array}{c}\text { Corrected Inter-Total } \\
\text { Correlation }\end{array}$ & $\alpha$ \\
\hline Attitude: Importance of recycling-IMP & & 0.821 \\
\hline Recycling will reduce pollution. & 0.709 & \\
\hline Recycling is important to save natural resources. & 0.748 & \\
\hline Recycling will save land that would be used as dump sites. & 0.623 & \\
\hline Attitude: Inconvenience of recycling-INC & & 0.816 \\
\hline Recycling household waste such as cans, bottles, and plastic containers is inconvenient. & 0.699 & \\
\hline There is not enough room to store the items being recycled. & 0.622 & \\
\hline Recycling is too much trouble. & 0.695 & \\
\hline Subjective social norm-SN & & 0.754 \\
\hline Most people who are important to me think that I should recycle my household waste. & 0.605 & \\
\hline Most people who are important to me would approve of me recycling my household waste. & 0.605 & \\
\hline Moral norm-MN & & 0.795 \\
\hline It would be wrong of me not to recycle my household waste. & 0.594 & \\
\hline I would feel guilty if I did not recycle my household waste. & 0.667 & \\
\hline Not recycling goes against my principles. & 0.581 & \\
\hline Everybody should share the responsibility to recycle household waste. & 0.589 & \\
\hline Warm glow-WGL & & 0.913 \\
\hline I like to contribute to the protection of the environment by recycling. & 0.846 & \\
\hline I have the feeling of contribution to the well-being of humanity when recycling. & 0.810 & \\
\hline Recycling household wastes makes me feel good. & 0.771 & \\
\hline I am happy with myself whenever recycling household wastes. & 0.797 & \\
\hline Recycling behavior $-R B$ & & 0.862 \\
\hline I recycle metal cans used at home. & 0.691 & \\
\hline I recycle plastic containers used at home. & 0.767 & \\
\hline I recycle glass jars/bottles used at home. & 0.772 & \\
\hline
\end{tabular}

\subsection{Descriptive Statistics and Correlations}

The means, standard deviation (SD), and correlations among constructs are presented in Table 3. The respondents indicated a relatively high level of social influence $(M=3.97)$, followed by attitude towards the importance of recycling $(\mathrm{M}=3.36)$ and attitude towards the inconvenience of recycling $(M=3.28)$. Nevertheless, they did not recycle household waste frequently $(M=2.91)$. The bivariate correlation coefficients showed that all the five predictors (recycling attitudes, social norm, personal norm, and warm glow) were significantly correlated to the dependent variable (recycling behavior). Additionally, all correlations between constructs were less than 0.6 , indicating that multicollinearity was not likely to affect the measures [92].

Table 3. Descriptive statistics and correlations.

\begin{tabular}{cccccccc}
\hline & Mean & SD & IMP & INC & SN & MN & WGL \\
\hline IMP & 3.363 & 0.988 & & & & \\
INC & 3.281 & 0.959 & $-0.397^{* *}$ & & & \\
SN & 3.976 & 0.915 & $0.288^{* *}$ & $-0.102^{*}$ & & \\
MN & 2.855 & 1.040 & $0.530^{* *}$ & $-0.457^{* *}$ & $0.230^{* *}$ & & \\
WGL & 2.849 & 1.036 & $0.418^{* *}$ & $-0.038^{\text {ns }}$ & $0.073^{\text {ns }}$ & $0.452^{* *}$ & \\
RB & 2.913 & 1.067 & $0.595^{* *}$ & $-0.367^{* *}$ & $0.278^{* *}$ & $0.438^{* *}$ & $0.323^{* *}$ \\
\hline \multicolumn{8}{c}{$p<0.011^{*} p<0.05$; $^{\text {ns }}$ not significant. }
\end{tabular}

\subsection{Hypotheses Testing}

Multiple regression analysis was conducted to test the proposed hypotheses. Such an analysis technique was selected because it enables to assess the relationship between a single dependent variable and multiple independent variables [93]. In compliance with the multiple regression method, 
each independent variable is weighted to ensure maximal prediction of the single dependent variable from the set of independent variables [91]. Furthermore, a considerable number of researchers have used the regression technique in their studies of ethical and recycling behavior $[6,24,60,66,94,95]$.

Regression assumptions were checked using guidelines from Allen et al. [93]. First, boxplots and histograms showed that each variable was normally distributed as well as free from univariate outliers. Second, partial plots and scatterplots supported the assumptions of linearity and homoscedasticity. Third, multicollinearity was further examined by using tolerance value and variance inflation factor (VIF). The statistics showed that the lowest tolerance value was 0.55 and the highest VIF was 1.83; hence multicollinearity would not affect the outcome of the multiple regression $[91,96]$. Fourth, the scatterplot of standardized residuals against standardized predicted values was used to assess the assumptions of normality, linearity, and homoscedasticity of residuals. According to Figure 2, there were not any clear patterns in the spread of points and the points tended to cluster towards the middle of the plot; hence the assumptions were met.

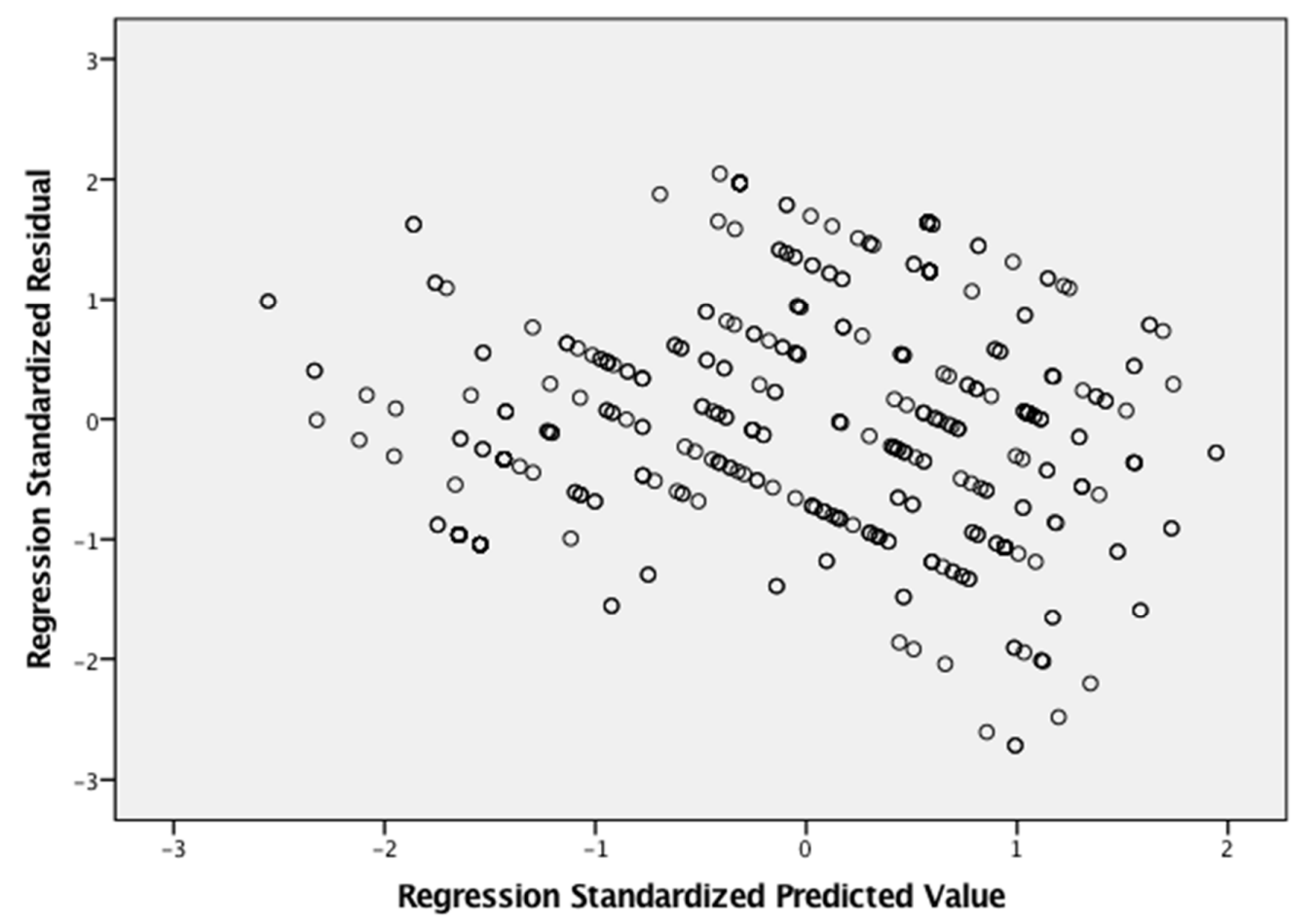

Figure 2. Scatterplot of standardized residuals against standardized predicted values.

In the multiple regression analysis, the final scales of all the constructs were created by calculating the average across the individual item scores. The results showed that the five predictors in combination explained a significant 40 per cent of the variance in recycling behavior, $R^{2}=0.403, F(5,480)=64.746$, $p<0.001$. As shown in Table 4, attitude towards the importance of recycling, subjective social norms, and warm glow were positively associated with recycling behavior. Hence $\mathrm{H}_{1}, \mathrm{H}_{3}$, and $\mathrm{H}_{5}$ were all supported in this study. As expected, attitude toward the inconvenience was negatively associated with recycling behavior; thus, $\mathrm{H}_{2}$ was accepted. Nevertheless, the relationship between moral norms and recycling behavior was not significant; thus, $\mathrm{H}_{4}$ was rejected. Among the significant positive predictors, the standardized regression coefficients demonstrated that attitude towards the importance of recycling $(\beta=0.421, p<0.001)$ had the strongest association with conservation behavior, followed by subjective social norms $(\beta=0.117, p<0.01)$ and warm glow $(\beta=0.099, p<0.05)$, respectively. By contrast, attitude toward the inconvenience of recycling $(\beta=-0.150, p<0.001)$ significantly reduced recycling behavior. 
Table 4. Hypothesis testing.

\begin{tabular}{cccccc}
\hline & Paths & & $\boldsymbol{\beta}$ & $\boldsymbol{t}$-Value & Hypotheses Supported \\
\hline IMP & $\rightarrow$ & RB & 0.421 & $9.233^{* * *}$ & $\mathrm{H}_{1}$ : Accepted \\
INC & $\rightarrow$ & RB & -0.150 & $-3.549^{* * *}$ & $\mathrm{H}_{2}$ : Accepted \\
SN & $\rightarrow$ & RB & 0.117 & $3.149^{* *}$ & $\mathrm{H}_{3}$ : Accepted \\
MN & $\rightarrow$ & RB & 0.074 & $1.545^{\mathrm{ns}}$ & $\mathrm{H}_{4}$ : Rejected \\
WGL & $\rightarrow$ & RB & 0.099 & $2.334^{*}$ & $\mathrm{H}_{5}$ : Accepted \\
\hline \multicolumn{2}{r}{${ }^{* * *} p<0.001 ;{ }^{* *} p<0.01 ;{ }^{*} p<0.05{ }^{\text {ns }}$ not significant. $\beta$ : standardized regression coefficient. }
\end{tabular}

\section{Discussion and Implications}

Recycling has received increasing attention from both researchers in the ethical and sustainable literature and market-based organizations. Understanding determinants affecting household recycling therefore makes a major contribution to the evolving literature, as well as provides important managerial implications. The current research builds upon theories from marketing, psychology, and economics to better understand how attitudes, norms, and warm glow influence recycling behavior. By focusing on Vietnam, the current research also extends knowledge about sustainable behavior in emerging markets which are the major culprits in terms of greenhouse gas emissions [97].

\subsection{Theoretical Implications}

The findings revealed various influencers of household recycling which demonstrate the complexity of benefits and motivations associated with ethical and sustainable behavior $[3,81,98,99]$. As expected, specific recycling attitudes (importance and inconvenience) were important factors influencing recycling behavior. This echoes previous studies in developed countries [52,56]. The finding that attitude towards the importance of recycling for environmental protection was the strongest influencer is in line with earlier research $[53,100]$. That is, people are engaged in household recycling mainly because they believe that such behavior contributes to environmental protection. By contrast, recycling behavior is impeded by personal inconvenience. More specifically, people who believe that they do not have enough room for storing recyclable materials and that recycling household wastes is inconvenient were less likely to recycle. This finding is similar to that obtained in studies by De Young [49] and Tonglet et al. [25].

The relationship between subjective social norms and recycling behavior was positive and significant. Whilst this finding supports several research findings [25,31], it contradicts studies in Greece [30] and the US [6], which demonstrate recycling behavior is not motivated by group and social norms. A possible explanation for the significant relationship is that Vietnam is a collectivist society [48]; hence Vietnamese people pay great attention to family and social norms. Interestingly, moral norms did not exert a significant impact on recycling. This negates the common finding that personal moral norms play a significant role in predicting recycling behavior in affluent countries $[30,53,101]$. This could be explained by the norm activation process initiated by Schwartz [102] who suggests that feelings of moral obligation might be deactivated by denial of responsibility which stems from personal cost anticipation. Hence, it is reasonable to conclude that Vietnamese people do not feel morally obliged to recycle household wastes because of perceived inconvenience and trouble associated with the behavior.

The positive direct relationship between warm glow and recycling behavior was also found. This validates the Theory of Warm-Glow Giving [72] in the economics literature, as well as it emphasizes the intrinsic motivation and satisfaction in the psychology discipline [73,74]. Specifically, people were motivated by the intrinsic rewards, i.e., the warm glow feeling of well-being when engaging in recycling behavior. 


\subsection{Managerial Implications}

In addition to efforts from the Governments and sustainable campaigners, market-based organizations have increasingly engaged in environmentally sustainable programs. The findings of this study have important implications for strategies aimed at promoting recycling behavior. Specifically, the insights into facilitators and barriers of recycling behavior gained in this study provide valuable inputs for developing effective interventional strategies. Given the prominence of attitude about the importance of recycling, communication and educational programs should emphasize how household recycling saves natural resources as well as reduce pollution. Such programs will increase people's awareness and beliefs about environmental benefits of recycling which in turn would motivate them to recycle household wastes.

With regard to the significance of subjective social norms, public media campaigns should feature opinion leaders and attractive communicators who can effectively apply social pressure to perform recycling behavior. Furthermore, establishment of recycling clubs will facilitate knowledge sharing and social interaction, which enhance social influence. To encourage the connection between warm glow and recycling, campaigns should deliver compelling messages emphasizing intrinsic rewards when recycling, e.g., feel good when doing the right thing for the environment and society. Communication campaigns should also use fun and enjoyment themes which would foster positive feelings amongst the target audience.

Lastly, organizations should make every effort to make recycling more convenient. Households should be educated about recyclable solid wastes and recycle bins. Providing households with sufficient recycle bins is vital to address the lack of room for storing recyclable materials. To facilitate change in beliefs, information strategies should stress that recycling does not take too much extra time and effort as people perceive that to be. Additionally, clear and concise printed guidelines for recycling should be delivered to households.

\section{Limitations and Future Research}

There are several limitations to the current study. First, human values-such as biospheric, altruistic, and egoistic human values-should be included as exogenous variables in the proposed model. Such additional personal values might possibly improve the model's sufficiency in predicting recycling behavior. Second, a mixed research methodology which includes qualitative data using in-depth interviews from a representative sample would certainly enrich the overall findings of this study. Third, using more advanced statistical software programs such as AMOS, Mplus, and R would allow for specifying covariance among variables and better understanding of effect sizes. Fourth, the choice of destination where this study took place (i.e., Vietnam) might limit the generalizability of the findings because of social and cultural differences. Replication of this study should be considered to test the generalization of this model in other contexts such as in other South East Asian countries.

Future research should consider the possibility of investigating changes in Vietnamese consumers' attitudes, norms, and warm glow effect over time by conducting a longitudinal study. Finally, whilst not the intent of this study, the data lends itself to exploring the impact of the different segmentation and socio-demographic variables of the respondents.

Author Contributions: The authors contributed equally to this research. The Ninh Nguyen and Antonio Lobo were responsible for the model, research design, and writing of the manuscript. Hoang Viet Nguyen and The Son Dao were responsible for the data collection and analyses.

Conflicts of Interest: The authors have no conflict of interest.

\section{References}

1. Balderjahn, I.; Buerke, A.; Kirchgeorg, M.; Peyer, M.; Seegebarth, B.; Wiedmann, K.-P. Consciousness for sustainable consumption: Scale development and new insights in the economic dimension of consumers' sustainability. AMS Rev. 2013, 3, 181-192. [CrossRef] 
2. McDonagh, P.; Prothero, A. Sustainability marketing research: Past, present and future. J. Mark. Manag. 2014, 30, 1186-1219. [CrossRef]

3. Moraes, C.; Carrigan, M.; Szmigin, I. The coherence of inconsistencies: Attitude-behavior gaps and new consumption communities. J. Mark. Manag. 2012, 28, 103-128. [CrossRef]

4. Shaw, D.; McMaster, R.; Newholm, T. Care and commitment in ethical consumption: An exploration of the 'attitude-behavior gap'. J. Bus. Ethics 2016, 136, 251-265. [CrossRef]

5. Ngoc, U.N.; Schnitzer, H. Sustainable solutions for solid waste management in southeast Asian countries. Waste Manag. 2009, 29, 1982-1995. [CrossRef] [PubMed]

6. Schwab, N.; Harton, H.C.; Cullum, J.G. The effects of emergent norms and attitudes on recycling behavior. Environ. Behav. 2014, 46, 403-422. [CrossRef]

7. Hopper, J.R.; Nielsen, J.M. Recycling as altruistic behavior: Normative and behavioral strategies to expand participation in a community recycling program. Environ. Behav. 1991, 23, 195-220. [CrossRef]

8. Ebreo, A.; Vining, J. How similar are recycling and waste reduction? Future orientation and reasons for reducing waste as predictors of self-reported behavior. Environ. Behav. 2001, 33, 424-448. [CrossRef]

9. Troschinetz, A.M.; Mihelcic, J.R. Sustainable recycling of municipal solid waste in developing countries. Waste Manag. 2009, 29, 915-923. [CrossRef] [PubMed]

10. Lave, L.B.; Hendrickson, C.T.; Conway-Schempf, N.M.; McMichael, F.C. Municipal solid waste recycling issues. J. Environ. Eng. 1999, 125, 944-949. [CrossRef]

11. McCarty, J.A.; Shrum, L.J. The recycling of solid wastes: Personal values, value orientations, and attitudes about recycling as antecedents of recycling behavior. J. Bus. Res. 1994, 30, 53-62. [CrossRef]

12. Thanh, N.P.; Matsui, Y.; Fujiwara, T. Assessment of plastic waste generation and its potential recycling of household solid waste in Can Tho city, Vietnam. Environ. Monit. Assess. 2011, 175, 23-35. [CrossRef] [PubMed]

13. Stephan, U.; Patterson, M.; Kelly, C.; Mair, J. Organizations driving positive social change: A review and an integrative framework of change processes. J. Manag. 2016, 42, 1250-1281. [CrossRef]

14. Carrigan, M.; Attalla, A. The myth of the ethical consumer-Do ethics matter in purchase behavior? J. Consum. Mark. 2001, 18, 560-578. [CrossRef]

15. Lioui, A.; Sharma, Z. Environmental corporate social responsibility and financial performance: Disentangling direct and indirect effects. Ecol. Econ. 2012, 78, 100-111. [CrossRef]

16. Huang, C.L.; Kung, F.H. Environmental consciousness and intellectual capital management: Evidence from Taiwan's manufacturing industry. Manag. Decis. 2011, 49, 1405-1425. [CrossRef]

17. King, A.; Lenox, M. Exploring the locus of profitable pollution reduction. Manag. Sci. 2002, 48, $289-299$. [CrossRef]

18. Molina-Azorín, J.F.; Claver-Cortés, E.; Maria, D.L.G.; Tarí, J.J. Green management and financial performance: A literature review. Manag. Decis. 2009, 47, 1080-1100. [CrossRef]

19. Shrum, L.J.; Lowrey, T.M.; McCarty, J.A. Recycling as a marketing problem: A framework for strategy development. Psychol. Mark. 1994, 11, 393-416. [CrossRef]

20. Kronrod, A.; Grinstein, A.; Wathieu, L. Go green! Should environmental messages be so assertive? J. Mark. 2012, 76, 95-102. [CrossRef]

21. Ajzen, I. The theory of planned behavior. Organ. Behav. Hum. Decis. Processes 1991, 50, 179-211. [CrossRef]

22. Fishbein, M. A theory of reasoned action: Some applications and implications. Neb. Symp. Motiv. 1979, 27, 65-116.

23. Davies, J.; Foxall, G.R.; Pallister, J. Beyond the intention-behavior mythology: An integrated model of recycling. Mark. Theory 2002, 2, 29-113. [CrossRef]

24. Terry, D.J.; Hogg, M.A.; White, K.M. The theory of planned behavior: Self-identity, social identity and group norms. Br. J. Soc. Psychol. 1999, 38, 225-244. [CrossRef] [PubMed]

25. Tonglet, M.; Phillips, P.S.; Read, A.D. Using the theory of planned behavior to investigate the determinants of recycling behavior: A case study from Brixworth, UK. Resour. Conserv. Recycl. 2004, 41, 191-214. [CrossRef]

26. Mahmud, S.N.D.; Osman, K. The determinants of recycling intention behavior among the Malaysian school students. Procedia Soc. Behav. Sci. 2010, 9, 119-124. [CrossRef]

27. Thøgersen, J. Recycling and morality: A critical review of the literature. Environ. Behav. 1996, 28, 536-558. [CrossRef] 
28. Bratt, C. The impact of norms and assumed consequences on recycling behavior. Environ. Behav. 1999, 31, 630-656. [CrossRef]

29. Shaw, D.; Shiu, E.; Clarke, I. The contribution of ethical obligation and self-identity to the theory of planned behavior: An exploration of ethical consumers. J. Mark. Manag. 2000, 16, 879-894. [CrossRef]

30. Botetzagias, I.; Dima, A.-F.; Malesios, C. Extending the theory of planned behavior in the context of recycling: The role of moral norms and of demographic predictors. Resour. Conserv. Recycl. 2015, 95, 58-67. [CrossRef]

31. Abbott, A.; Nandeibam, S.; O'Shea, L. Recycling: Social norms and warm-glow revisited. Ecol. Econ. 2013, 90, 10-18. [CrossRef]

32. Taufik, D.; Bolderdijk, J.W.; Steg, L. Acting green elicits a literal warm glow. Nat. Clim. Chang. 2015, 5, 37-40. [CrossRef]

33. De Young, R. Encouraging environmentally appropriate behavior: The role of intrinsic motivation. J. Environ. Syst. 1985, 15, 281-292. [CrossRef]

34. De Young, R. New ways to promote proenvironmental behavior: Expanding and evaluating motives for environmentally responsible behavior. J. Soc. Issues 2000, 56, 509-526. [CrossRef]

35. Cleveland, M.; Kalamas, M.; Laroche, M. "It's not easy being green": Exploring green creeds, green deeds, and internal environmental locus of control. Psychol. Mark. 2012, 29, 293-305. [CrossRef]

36. Project for Implementation Support for 3R INITIATIVE in Hanoi City to Contribute to the Development of a Sound Material-Cycle Society (3R-HN). Available online: https://www.jica.go.jp/vietnam/english/ activities/activity15.html (accessed on 20 October 2016).

37. Nguyen, T.T.P.; Zhu, D.; Le, N.P. Factors influencing waste separation intention of residential households in a developing country: Evidence from Hanoi, Vietnam. Habitat Int. 2015, 48, 169-176. [CrossRef]

38. Chi, N.K.; Long, P.Q. Solid waste management associated with the development of 3R initiatives: Case study in major urban areas of Vietnam. J. Mater. Cycles Waste Manag. 2011, 13, 25-33. [CrossRef]

39. Recycles Vietnam. Available online: http://www.vietnamrecycles.com (accessed on 21 October 2016).

40. HEPFU. Available online: http://www.hepfu.vn (accessed on 21 October 2016).

41. General Statistics Office of Vietnam. Statistical Handbook of Vietnam; General Satistics Office of Vietnam: Hanoi, Vietnam, 2014.

42. World Bank. Available online: http://data.worldbank.org/country/vietnam (accessed on 21 October 2016).

43. Euromonitor International. Consumer Lifestyles in Vietnam; Euromonitor International Ltd.: London, UK, 2016.

44. General Satistics Office of Vietnam. Statistical Yearbook of Vietnam; GSO: Hanoi, Vietnam, 2015.

45. De Koning, J.I.J.C.; Crul, M.R.M.; Wever, R.; Brezet, J.C. Sustainable consumption in Vietnam: An explorative study among the urban middle class. Int. J. Consum. Stud. 2015, 39, 608-618. [CrossRef]

46. Nguyen, T.N.; Lobo, A.; Greenland, S. Pro-environmental purchase behavior: The role of consumers' biospheric values. J. Retail. Consum. Serv. 2016, 33, 98-108. [CrossRef]

47. Nguyen, T.N.; Lobo, A.; Nguyen, H.L.; Phan, T.T.H.; Cao, T.K. Determinants influencing conservation behavior: Perceptions of Vietnamese consumers. J. Consum. Behav. 2016, 15, 560-570. [CrossRef]

48. Hofstede, G. Culture's Consequences: Comparing Values, Behaviors, Institutions, and Organizations across Nations, 2nd ed.; Sage: Thousand Oaks, CA, USA; London, UK, 2001.

49. De Young, R. Recycling as appropriate behavior: A review of survey data from selected recycling education programs in Michigan. Resour. Conserv. Recycl. 1990, 3, 253-266. [CrossRef]

50. Guagnano, G.A.; Stern, P.C.; Dietz, T. Influences on attitude-behavior relationships: A natural experiment with curbside recycling. Environ. Behav. 1995, 27, 699-718. [CrossRef]

51. Best, H.; Mayerl, J. Values, beliefs, attitudes: An empirical study on the structure of environmental concern and recycling participation values, beliefs, attitudes: An empirical study on the structure of environmental concern and recycling participation. Soc. Sci. Q. 2013, 94, 691-714. [CrossRef]

52. McCarty, J.A.; Shrum, L.J. The influence of individualism, collectivism, and locus of control on environmental beliefs and behavior. J. Public Policy Mark. 2001, 20, 93-104. [CrossRef]

53. Vining, J.; Ebreo, A. Predicting recycling behavior from global and specific environmental attitudes and changes in recycling opportunities. J. Appl. Soc. Psychol. 1992, 22, 1580-1607. [CrossRef]

54. Do Valle, P.O.; Reis, E.; Menezes, J.; Rebelo, E. Behavioral determinants of household recycling participation: The Portuguese case. Environ. Behav. 2004, 36, 505-540. [CrossRef]

55. McCarty, J.A.; Shrum, L.J. A structural equation analysis of the relationships of personal values, attitudes and beliefs about recycling, and the recycling of solid waste products. Adv. Consum. Res. 1993, 20, 641-646. 
56. Vining, J.; Ebreo, A. What makes a recycler? A comparison of recyclers and nonrecyclers. Environ. Behav. 1990, 22, 55-73. [CrossRef]

57. Vicente, P.; Reis, E. Factors influencing households' participation in recycling. Waste Manag. Res. 2008, 26, 140-146. [CrossRef] [PubMed]

58. Biel, A.; Thøgersen, J. Activation of social norms in social dilemmas: A review of the evidence and reflections on the implications for environmental behavior. J. Econ. Psychol. 2007, 28, 93-112. [CrossRef]

59. Schultz, P.W. Changing behavior with normative feedback interventions: A field experiment on curbside recyling. Basic. Appl. Soc. Psychol. 1999, 21, 25-36. [CrossRef]

60. Biswas, A.; Licata, J.W.; McKee, D.; Pullig, C.; Daughtridge, C. The recycling cycle: An empirical examination of consumer waste recycling and recycling shopping behaviors. J. Public Policy Mark. 2000, 19, 93-105. [CrossRef]

61. Nielsen, L.; McGregor, S.L.T. Consumer morality and moral norms. Int. J. Consum. Stud. 2013, 37, 473-480. [CrossRef]

62. Schwartz, S.H.; Howard, J.A. Helping and cooperation: A self-based motivational model. In Cooperation and Helping Behavior: Theories and Research; Derlega, V.J., Grzelak, J., Eds.; Academic Press: Amsterdam, The Netherlands, 1982; pp. 327-353.

63. Caruana, R. Morality and consumption: Towards a multidisciplinary perspective. J. Mark. Manag. 2007, 23, 207-225. [CrossRef]

64. Szmigin, I.; Carrigan, M.; McEachern, M.G. The conscious consumer: Taking a flexible approach to ethical behavior. Int. J. Consum. Stud. 2009, 33, 224-231. [CrossRef]

65. Thøgersen, J. The motivational roots of norms for environmentally responsible behavior. Basic Appl. Soc. Psychol. 2009, 31, 348-362. [CrossRef]

66. Carrus, G.; Passafaro, P.; Bonnes, M. Emotions, habits and rational choices in ecological behaviors: The case of recycling and use of public transportation. J. Environ. Psychol. 2008, 28, 51-62. [CrossRef]

67. De Groot, J.I.M.; Steg, L. Relationships between value orientations, self-determined motivational types and pro-environmental behavioral intentions. J. Environ. Psychol. 2010, 30, 368-378. [CrossRef]

68. Moons, I.; De Pelsmacker, P. Emotions as determinants of electric car usage intention. J. Mark. Manag. 2012, 28, 195-237. [CrossRef]

69. Steg, L.; Bolderdijk, J.W.; Keizer, K.; Perlaviciute, G. An integrated framework for encouraging pro-environmental behavior: The role of values, situational factors and goals. J. Environ. Psychol. 2014, 38, 104-115. [CrossRef]

70. Clark, C.F.; Kotchen, M.J.; Moore, M.R. Internal and external influences on pro-environmental behavior: Participation in a green electricity program. J. Environ. Psychol. 2003, 23, 237-246. [CrossRef]

71. Andreoni, J. Giving with impure altruism: Applications to charity and ricardian equivalence. J. Political Econ. 1989, 97, 1447-1458. [CrossRef]

72. Andreoni, J. Impure altruism and donations to public goods: A theory of warm-glow giving. Econ. J. 1990, 100, 464-477. [CrossRef]

73. Deci, E.L. Effects of externally mediated rewards on intrinsic motivation. J. Pers. Soc. Psychol. 1971, 18, 105-115. [CrossRef]

74. De Young, R. Some psychological aspects of reduced consumption behavior the role of intrinsic satisfaction and competence motivation. Environ. Behav. 1996, 28, 358-409. [CrossRef]

75. Ryan, R.M.; Deci, E.L. Intrinsic and extrinsic motivations: Classic definitions and new directions. Contemp. Educ. Psychol. 2000, 25, 54-67. [CrossRef] [PubMed]

76. Ryan, R.M.; Deci, E.L. Self-determination theory and the facilitation of intrinsic motivation, social development, and well-being. Am. Psychol. 2000, 55, 68-78. [CrossRef] [PubMed]

77. Hartmann, P.; Apaolaza Ibáñez, V. Green value added. Mark. Intell. Plan. 2006, 24, 673-680. [CrossRef]

78. Hartmann, P.; Apaolaza Ibáñez, V. Consumer attitude and purchase intention toward green energy brands: The roles of psychological benefits and environmental concern. J. Bus. Res. 2012, 65, 1254-1263. [CrossRef]

79. Memery, J.; Megicks, P.; Angell, R.; Williams, J. Understanding ethical grocery shoppers. J. Bus. Res. 2012, 65, 1283-1289. [CrossRef]

80. Vasileva, E.; Ivanova, D. Towards a sustainable consumer model: The case study of bulgarian recyclers. Int. J. Consum. Stud. 2014, 38, 475-484. [CrossRef] 
81. Shaw, D.; Shiu, E. Ethics in consumer choice: A multivariate modelling approach. Eur. J. Mark. 2003, 37, 1485-1498. [CrossRef]

82. Fuller, T.D.; Edwards, J.N.; Vorakitphokatorn, S.; Sermsri, S. Using focus groups to adapt survey instruments to new populations: Experience from a developing country. In Successful Focus Groups: Advancing the State of the Art; Morgan, D.L., Ed.; SAGE Publications, Inc.: Thousand Oaks, CA, USA, 1993; pp. 89-105.

83. Nunes, P.A.L.D.; Schokkaert, E. Identifying the warm glow effect in contingent valuation. J. Environ. Econ. Manag. 2003, 45, 231-245. [CrossRef]

84. Presser, S.; Couper, M.P.; Lessler, J.T.; Martin, E.; Martin, J.; Rothgeb, J.M.; Singer, E. Methods for testing and evaluating survey questions. Public Opin. Q. 2004, 68, 109-130. [CrossRef]

85. Bell, J. Doing Your Research Project; McGraw-Hill Education: New York, NY, USA, 2010.

86. Podsakoff, P.M.; MacKenzie, S.B.; Lee, J.-Y.; Podsakoff, N.P. Common method biases in behavioral research: A critical review of the literature and recommended remedies. J. Appl. Psychol. 2003, 88, 879-903. [CrossRef] [PubMed]

87. MacKenzie, S.B.; Podsakoff, P.M. Common method bias in marketing: Causes, mechanisms, and procedural remedies. J. Retail. 2012, 88, 542-555. [CrossRef]

88. Bagozzi, R.P.; Yi, Y. Assessing method variance in multitrait-multimethod matrices: The case of self-reported affect and perceptions at work. J. Appl. Psychol. 1990, 75, 547-560. [CrossRef]

89. Malhotra, N.K.; Kim, S.S.; Patil, A. Common method variance in is research: A comparison of alternative approaches and a reanalysis of past research. Manag. Sci. 2006, 52, 1865-1883. [CrossRef]

90. Churchill, G.A. A paradigm for developing better measures of marketing constructs. J. Mark. Res. 1979, 16, 64-73. [CrossRef]

91. Hair, J.F.; Black, W.C.; Babin, B.J.; Anderson, R.E. Multivariate Data Analysis, 7th ed.; Prentice Hall: Upper Saddle River, NJ, USA, 2010.

92. Grewal, R.; Cote, J.A.; Baumgartner, H. Multicollinearity and measurement error in structural equation models: Implications for theory testing. Mark. Sci. 2004, 23, 519-529. [CrossRef]

93. Allen, P.; Bennett, K.; Heritage, B. SPSS Statistics Version 22: A Practical Guide; Cengage Learning Australia: South Melbourne, Australia, 2014.

94. Castro, P.; Garrido, M.; Reis, E.; Menezes, J. Ambivalence and conservation behavior: An exploratory study on the recycling of metal cans. J. Environ. Psychol. 2009, 29, 24-33. [CrossRef]

95. Megicks, P.; Memery, J.; Angell, R.J. Understanding local food shopping: Unpacking the ethical dimension. J. Mark. Manag. 2012, 28, 264-289. [CrossRef]

96. O'brien, R.M. A caution regarding rules of thumb for variance inflation factors. Qual. Quant. 2007, 41, 673-690. [CrossRef]

97. Hsu, A. Environmental Performance Index; Yale University: New Have, CT, USA, 2016.

98. Lindenberg, S.; Steg, L. Normative, gain and hedonic goal frames guiding environmental behavior. J. Soc. Issues 2007, 63, 117-137. [CrossRef]

99. Moisander, J. Motivational complexity of green consumerism. Int. J. Consum. Stud. 2007, 31, 404-409. [CrossRef]

100. Nigbur, D.; Lyons, E.; Uzzell, D. Attitudes, norms, identity and environmental behavior: Using an expanded theory of planned behavior to predict participation in a kerbside recycling programme. Br. J. Soc. Psychol. 2010, 49, 259-284. [CrossRef] [PubMed]

101. Thøgersen, J.; Grunert-Beckmann, S.C. Values and attitude formation towards emerging attitude objects: From recycling to general, waste minimizing behavior. Adv. Consum. Res. 1997, 24, 182-189.

102. Schwartz, S.H. Normative influences on altruism. Adv. Exp. Soc. Psychol. 1977, 10, 221-279.

(c) 2017 by the authors; licensee MDPI, Basel, Switzerland. This article is an open access article distributed under the terms and conditions of the Creative Commons Attribution (CC BY) license (http:/ / creativecommons.org/licenses/by/4.0/). 